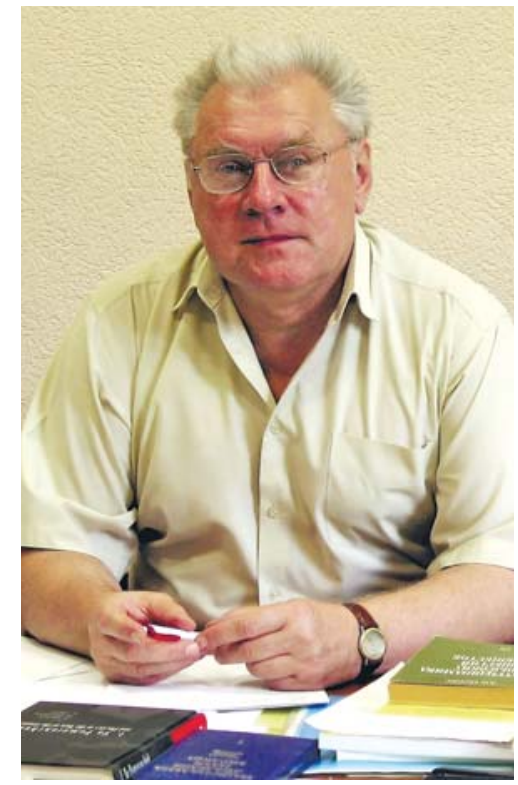

ШульГА

Микола Федорович академік НАН України, академік-секретар Відділення ядерної фізики та енергетики НАН України, генеральний директор ННЦ «Харківський фізико-технічний інститут»

\section{5 РОКІВ ЛАБОРАТОРІЇ № 1 АТОМНОГО ПРОЄКТУ СРСР}

Шановний Анатолію Глібовичу!

Шановні учасники сесії Загальних зборів НАН України!

Передусім пропоную схвалити звітну доповідь президента Національної академії наук України академіка НАН України Анатолія Глібовича Загороднього й прийняти ï положення як керівництво у подальшій роботі.

Я також повністю згоден і підтримую виступ академіка НАН України Вадима Михайловича Локтєва, особливо в тому, що стосується позиції нинішніх керівників держави та їхнього ставлення і до розвитку наукових досліджень, і до Академії.

У своїй доповіді я наведу коротку інформацію щодо спорудження в ННЦ ХФТІ установки «Джерело нейтронів» за спільним проєктом США і України. Це найбільша фізична установка, яка споруджується в Україні за часів її незалежності. Аналогів такої установки немає у світі. Але для кращого розуміння я розпочну з тих підстав, які зрештою і привели до спорудження цієї установки саме в Україні.

Другого березня цього року виповнилося 75 років від часу створення в УФТІ Лабораторії № 1 Атомного проєкту СРСР. Сам проєкт було започатковано в 1943 р. Тоді було організовано Лабораторію № 2 Атомного проєкту, яка потім перетворилася на знаменитий Курчатовський інститут.

Тоді чому ж Лабораторія № 1 була у Харкові? Одна з причин - це данина поваги тому, що ядерна фізика як напрям досліджень у СРСР була ініційована роботами, які проводилися на початку 1930-х років в УФТІ. Саме тут у 1932 р. вперше в СРСР А. Вальтером, Г. Латишевим, О. Лейпунським та К. Синельниковим було здійснено розщеплення атомного ядра. Потім у 1940 р. після відкриття можливості ланцюгової реакції в урані співробітник УФТІ Фрідріх Ланге та його молоді колеги Віктор Маслов і Володимир Шпінель у 1940 р. подали заявку на винахід фактично атомної бомби - «Об использовании урана как взрывчатого и ядовитого вещества». Вони вперше запропонували схему, яка стала згодом загальноприйнятою, - схему 
вибуху з використанням звичайної вибухівки для створення критичної маси 3 подальшим ініціюванням ланцюгової реакції.

Однак заявку тоді не було підтримано ані в Академіі наук, ані в оборонній галузі. Рецензенти вважали, що «вона зараз не має під собою реального фундаменту. Крім того, по суті, в ній дуже багато фантастичного. ... Не підтверджується експериментальними даними». Після Хіросіми і Нагасакі заявлена схема набула експериментального підтвердження, але час уже минув.

Науковим керівником Лабораторії № 1 УФТІ, яка складалася з 13 секторів, у 1946 р. було призначено Ігоря Васильовича Курчатова, начальником Лабораторії - Кирила Дмитровича Синельникова (до речі, через два дні виповнюється 120 років від дня його народження), а його заступником - Антона Карловича Вальтера, який у 1965 р. побудував в УФТІ перший у Свропі прискорювач електронів на 2000 МеВ. Лабораторія № 1 існувала до 1956 р., на її основі з'явилися такі наукові напрями, як керований термоядерний синтез, фізика прискорювачів, радіаційне матеріалознавство та багато інших.

У 1994 р. на міждержавному рівні було прийнято рішення про без'ядерний статус України, яка тоді мала третій у світі ядерний потенціал. Останні запаси високозбагаченого урану було вивезено з України, а саме - з Харківського фізико-технічного інституту, в 2012 р.

Чи означало це повне припинення в Україні робіт з ядерної фізики? Нi, в жодному разі. ХФТІ запропонував американській стороні розпочати спільні роботи зі створення в Харківському фізико-технічному інституті ядерної дослідницької установки «Джерело нейтронів, засноване на підкритичній збірці, що керується лінійним прискорювачем електронів». Подібних установок сьогодні у світі немає і в найближче десятиліття не передбачається.

«Джерело нейтронів» є аналогом безпечного реактора, запропонованого колишнім директором ЦЕРНу Карло Рубіа. Великий інтерес до створення такої установки було виявлено як з американської, так і з української сторони.
Рішення про співпрацю США і України в цій галузі було прийнято в 2010 р., а в 2014 р. вже було споруджено будівлю установки і розпочалися роботи з налагодження внутрішнього обладнання. Створення установки профінансував уряд Сполучених Штатів Америки в розмірі вже понад 85 млн доларів США.

Інтерес до робіт у цій галузі великий, практично на всіх рівнях і в Україні, і в США. Так, у 2016 р. на контрольному запуску дослідницької ядерної підкритичної установки «Джерело нейтронів» були присутні Президент України Петро Порошенко та посол США в Україні Джеффрі Паєтт, відбулися також візити керівництва Департаменту енергетики США, американських учених, представників МОH України, керівництва Харківської області, українських політичних і громадських діячів.

Зараз триває завершальна стадія фізичного пуску «Джерела нейтронів» - завантаження до активної зони 38 тепловидільних збірок. Потім розпочнеться наступний етап дослідно-промислової експлуатації установки доведення їі до проєктних параметрів, тобто значне підвищення струму прискорювача (а прискорювачів 3 подібними параметрами у світі поки немає), діагностика параметрів системи за великих струмів та ін. На все це знадобиться ще приблизно півтора року. А що далі?

Вже зараз обговорюється питання створення на основі ядерної підкритичної установки «Джерело нейтронів» міжнародного наукового центру. $Є$ попередня домовленість з Департаментом енергетики США і МАГАТЕ про проведення в Харківському фізико-технічному інституті робочої наради, присвяченої цьому питанню. Планувалося, що ця нарада відбудеться ще минулого року, в ННЦ ХФТІ мали приїхати близько 20 провідних фахівців з Департаменту енергетики США і МАГАТЕ для обговорення подальшої програми робіт на установці, але на заваді стали карантинні обмеження, пов'язані з пандемією COVID-19. Великий інтерес до створення міжнародного наукового центру на базі установки і проведення на ній спільних експериментів висловлюють не лише США, а 
й низка інших країн, таких як Велика Британія, Франція, Китай тощо.

Кілька місяців тому надійшла пропозиція від досить великої швейцарської корпорації DAES (Development of Advanced Engineering Solutions) про проведення найближчим часом спільної наради, з тим щоб визначити спільні інтереси щодо експлуатації установки. Річ у тім, що Швейцарія зараз розвиває напрям зі створення безпечного ядерного реактора, аналогічного нашій установці «Джерело нейтронів», але з більшим струмом нейтронів. Тому вони цікавляться досвідом, який уже є в ННЦ ХФТІ із запуску такої установки, та багатьма технологічними аспектами, зокрема щодо вимірювання коефіцієнта реактивності.

Згідно з договором, після завершення етапу дослідно-промислової експлуатації установки іiї буде передано Україні «під ключ» з умовою, що подальша промислова експлуатація фінансуватиметься українською стороною.

В останні роки академік Б.Є. Патон приділяв велику увагу створенню міжнародного наукового центру з пайовою участю країн-учасниць у фінансуванні наукових експериментів. За його ініціативою було проведено кілька вузьких нарад у Президії НАН України, присвячених цьому питанню. Він також запропонував коротку назву для майбутнього центру - «МініЦЕРН». Вважаю за доцільне відродити такі наради в Президії НАН України. У справі створення центру ми розраховуємо на підтримку Академіі.
У 2019 р. в США в Університеті Дж. Вашингтона було проведено нараду керівництва Департаменту енергетики США, кількох американських корпорацій, зокрема компанії Westinghouse, ННЦ ХФТІ та представників посольства України в США і низки провідних українських закладів вищої освіти з метою надання допомоги Україні в підготовці кадрів у галузі ядерної енергетики. Під час засідання ідея створення міжнародного центру в Харкові викликала великий інтерес. Вирішили подібну нараду провести в Україні у 2021 або 2022 р.

За браком часу я не буду зупинятися на проблемах організації робіт зі спорудження та запуску установки, тим більше, що вони такі самі, як і практично в кожному інституті Академії. Це вкрай недостатнє фінансування, брак кадрів, від'їзд провідних фахівців та молодих учених за кордон, застаріле обладнання, малі зарплати та багато іншого. Все, що було зроблено і робиться зараз, стало можливим завдяки досвіду старшого покоління та ентузіазму молодих фахівців. Тобто, як кажуть, є поки що порох у порохівницях.

Більш розширений варіант того, що я розповів, було озвучено приблизно 2 місяці тому на семінарі фізико-технічного факультету Харківського національного університету ім. В.Н. Каразіна. 3 матеріалами цієї доповіді можна ознайомитися на YouTube-каналі - Shulga: «75 Years Lab № 1 (Atomic project)» (https:// www.youtube.com/watch? $v=$ pC8T3jlVDQw).

Дякую за увагу! 